\title{
Electrical Waste Fibers Impact on Mechanical and Durability Properties of Concrete
}

\author{
Ganesh Naidu Gopu ${ }^{1}$, A. Sofi ${ }^{2, *}$ \\ ${ }^{1}$ School of Civil Engineering, Vellore Institute of Technology, Vellore, 632014, Tamil Nadu, India \\ ${ }^{2}$ Department of Structural Engineering, School of Civil Engineering, Vellore Institute of Technology, Vellore, 632014, Tamil Nadu, \\ India
}

Received June 25, 2021; Revised August 3, 2021; Accepted September 8, 2021

\section{Cite This Paper in the following Citation Styles}

(a): [1] Ganesh Naidu Gopu, A. Sofi , "Electrical Waste Fibers Impact on Mechanical and Durability Properties of Concrete," Civil Engineering and Architecture, Vol. 9, No. 6, pp. 1854-1868, 2021. DOI: 10.13189/cea.2021.090618.

(b): Ganesh Naidu Gopu, A. Sofi (2021). Electrical Waste Fibers Impact on Mechanical and Durability Properties of Concrete. Civil Engineering and Architecture, 9(6), 1854-1868. DOI: 10.13189/cea.2021.090618.

Copyright $\subseteq 2021$ by authors, all rights reserved. Authors agree that this article remains permanently open access under the terms of the Creative Commons Attribution License 4.0 International License

\begin{abstract}
Major aspects that were considered while designing a structure are safety and serviceability. Serviceability is also called as life span of structure reduces, when exposed to severe environments. Solid waste management in developing nations has been growing everyday, which influenced the scientists and researchers around the world in recycling and application of solid waste in various fields. Introduction of waste and recycled fibers in concrete is quite prominent from last few decades. In this research, electric waster copper fibers (EWCF) are added to concrete to test mechanical properties and chloride ion penetration that could reduce the durability of concrete. Adopted percentages of copper fibers added to the concrete are $0,0.25,0.5,0.75,1.00,1.25,1.50,1.75$ and 2.00 for volume of concrete. Concrete introduced with EWCF was tested for compression, tensile, flexural and elastic modulus to determine mechanical behavior. Most optimal EWCF percentage of replacement that increased the strength of concrete is $1.0 \%$ in volume of concrete. Water absorption, sorptivity, acid attack, bulk diffusion and rapid chloride penetration test (RCPT) were performed on concrete with EWCF to evaluate the durability and microstructure performance. E-Glass and Steel fibers were also adopted in the study to compare the mechanical properties and durability. Optimum values for both strength and durability were determined from the experimental test results.
\end{abstract}

Keywords Electric Waste Copper Fibers, Mechanical Properties, Durability Properties, Recycling, Chloride Ion Diffusion

\section{Introduction}

Electrical and electronic waste is one of the world's most rapidly rising waste sources. E-waste is one of the biggest growth waste streams due to rising "market penetration" in emerging nations, "replacement market" in industrialized nations, and "high obsolescence rate." For Indian residents, globalization creates both pressure and motivation to enhance their environmental performance. India, as a developing nation, must strike a balance between monetary and natural execution. Green supply chain management (GSCM) is gaining traction as a viable option for Indian people looking to enhance their performance in these areas. More focus has been placed on resource conservation and environmental protection.

In general, small diameter electrical wires and communication cables do not undergo recycling and were directed to garbage dumping area. These fibers has an adverse effect on environment as they are non-biodegradable and releases toxic gases on reaction with moisture[1]. Electrical waste is transformed into fibers and were induced in concrete to increase strength and serviceability of structure[2]. In this paper, Electrical and communication cables were sleeved off to extract copper wire and were chopped into required dimensions and the fibers were adopted into study as electric waste copper fibers [3][4].

Fibers, when added to concrete, significantly affect parameters that could increase flexural, compressive, 
elastic and tensile behaviour of the concrete. Fibers play a vital role, and hence it is introduced in the concrete mix to arrest the cracks that occurred in normal concrete and also increases the freeze and thaw resistance of the concrete[5]. Fibers with different types and sizes are available in the market [6]. Electric grid glass initially used as electric wire isolator was later found to have increased the performance of concrete when added as fibers [7][8]. The glass fibers incorporated concrete expands the durability and mechanical properties [9], and vice versa. Excessive amount of glass fiber causes low workability and less modulus of elasticity of concrete [10]. E-glass fiber increases the electrical resistivity of the concrete [11]. Incorporating steel fibers in concrete can control the expansion of cracks and can reduce propagation rate. Steel fibers in concrete in appropriate proportions can increase both tension stiffening [12] and the fatigue strength of the reinforced concrete [13][14]. Steel fibers in contact with rebar act as sacrificial anodes to reduce the influence of corrosion which increases the serviceability of the structures [15][16]. Durability is an essential aspect of concrete structures[17]. The concrete structure should resist the weathering action, chemical attacks and physical aggression caused during their service life [18][19].

This research explores the behaviour of EWCF, GF, and SF incorporated concrete compared with conventional concrete to give optimum dosage of fibers incorporation.

\section{Methodology}

\subsection{Materials}

As a binding medium, OPC of 53-grade Ultratech cement was employed, and all properties were met in accordance with Indian standard code[20]. 20mm sized coarse aggregate with a density of $1540 \mathrm{~kg} / \mathrm{m}^{3}$ and fineness modulus 4.32, extracted from Chimakurthy quarry mines is adopted in the study. Fine aggregate adopted is natural sand with a dry bulk density of $1780 \mathrm{~kg} / \mathrm{m}^{3}$ and fineness modulus of 2.73[21]. Steel, glass and electric waste fibers are adopted in the study and the morphology of the fibers is shown in Figure 1 and physical characteristics were shown in Table 1.

Table 1. Characteristics of fibers

\begin{tabular}{|l|c|c|c|}
\hline Parameters of fibers & SF & GF & EWCF \\
\hline Shape & Straight & Straight & Straight \\
\hline Aspect ratio & 50 & 50 & 50 \\
\hline Diameter [mm] & 0.8 & 0.12 & 0.6 \\
\hline Length [mm] & 40 & 6 & 30 \\
\hline $\begin{array}{l}\text { Tensile strength of fibers } \\
{\left[\mathrm{N} / \mathrm{mm}^{2} \text { ] }\right.}\end{array}$ & 1220 & 1950 & 1366 \\
\hline
\end{tabular}

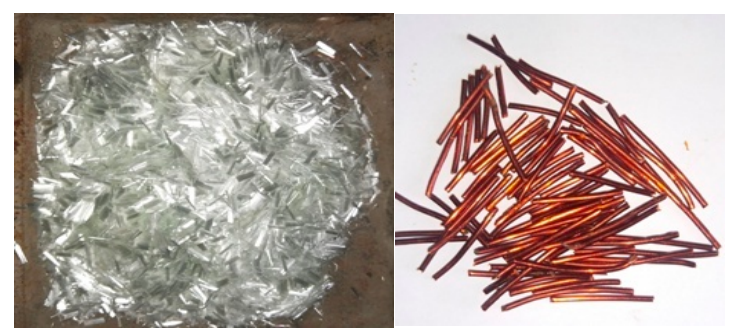

(a)

(b)

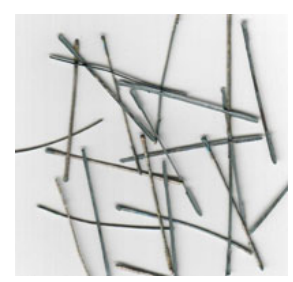

(c)

Figure 1. Morphology of (a) Glass fibers (b) Electric waste copper fibers (c) Steel Fibers

\subsection{Grade and Mix Proportion}

Grade of concrete adopted in the study is M40 and mix proportion was 1:1.71:2.39, designed as per Indian standard code [22]. Water to binder ratio was taken as 0.45 and fibers were incorporated in concrete randomly with volume fractions $0.25 \%, 0.50 \%, 0.75 \%, 1.0 \%, 1.25 \%$, $1.50 \%, 1.75 \%$ and $2.0 \%$. Care was taken during the process of adding fibers to the concrete to avoid damage of fibers and facilitate the uniform dispersion of fibers. Specimens were casted and cured for different durations to test as per Indian Standard guidelines.

\subsection{Test Procedures}

\subsubsection{Mechanical and Durability Tests}

Hardened property tests on concrete were done in accordance with Indian Standard code and ASTM codes, as shown in Table 2. Hardened concrete is tested for compression, flexural, split tensile strength and modulus of elasticity. The water absorption and permeability of voids were determined using water absorption and porosity tests. As per ASTM C 642-2006, the specimens were cast and tested. Water absorption was calculated by the following Equations. (1) - (2).

$$
\begin{aligned}
& \text { Initial water absorption } \%=\frac{\left(W_{2}-W_{1}\right)}{W_{1}} X 100 \\
& \text { Final water absorption } \%=\frac{\left(W_{3}-W_{1}\right)}{W_{1}} X 100
\end{aligned}
$$

Where, W1 is the oven-dried sample weight in the air, $\mathrm{W}_{2}$ and $\mathrm{W}_{3}$ are the weight of the surface dried saturated sample after 30 minutes and 96 hours respectively. 
The specimen was oven-dried before being immersed in water and weighed till it exceeded the constant weight.The initial 30-minute surface absorption and final absorption was estimated at 96 hours in all cases[23][24]. The porosity of the specimen can be determined from the difference between oven dried weight $\left(\mathrm{W}_{1}\right)$ and final weight of specimen $\left(\mathrm{W}_{3}\right)$.Concrete sorptivity was a quantity that calculates through capillary action, the level of penetration of unsaturated fluids into pores in concrete [18]. The experiment was conducted in accordance with ASTM C 642-82. Concrete cubes of size $100 \mathrm{~mm}$ were employed in this study. The samples were cured for 28 days and oven dried for 24hours. Later oven dried specimen is sealed on all sides maintaining uniform thickness with insulating water-resistant tape. Initial weight of the sample was calculated and immersed in water to a depth of $5-10 \mathrm{~mm}$. Over the course of two hours, the weight gain was measured at 30-minute intervals. The accumulated water absorption per unit area of the layer (i) can be calculated by using the formula for one-dimensional flow shown in Eq.(3)

$$
i=S \sqrt{\mathrm{t}}
$$

Where $\mathrm{S}$ - sorptivity by Capillarity and $\mathrm{t}$ - time elapsed

An acid attack test is conducted to predict resistance of concrete against acids. Nine specimens were kept soaked for 28, 56 and 90days in $3 \% \mathrm{H}_{2} \mathrm{SO}_{4}$ solution [25][26]. After 28 days of curing, specimens were taken out from curing tank and surface polished using a nylon brush. Later specimens are oven dried at $100^{\circ} \mathrm{C}$ for 24hours to find out the weight of the specimen. Throughout the test $\mathrm{pH}$ value of about four maintained constant. At regular intervals, the solution was replaced to obtained constant $\mathrm{pH}$ values. The visual appearance was then examined. Weight reduction and compressive strength reduction were estimated [27].

Table 2. Test parameters based on IS and ASTM codes

\begin{tabular}{|c|l|l|}
\hline Test & \multicolumn{1}{|c|}{$\begin{array}{c}\text { Specimen \& } \\
\text { dimensions (mm) }\end{array}$} & \multicolumn{1}{|c|}{ Standard code } \\
\hline Compressive test & Cubes (150X150X150) & $\begin{array}{l}\text { IS 516- Part (IV) } \\
2018\end{array}$ \\
\hline Split tensile test & $\begin{array}{l}\text { Cylindrical (Ø150 and } \\
\text { 300 Height) }\end{array}$ & IS 5816-2004 \\
\hline Flexural Test & Prism (100X100X500) & $\begin{array}{l}\text { IS 516- Part (IV) } \\
2018\end{array}$ \\
\hline Elasticity modulus & $\begin{array}{l}\text { Cylindrical (Ø150 and } \\
\text { 300 Height) }\end{array}$ & ASTM C469-02 \\
\hline $\begin{array}{c}\text { Water absorption } \\
\text { and Sorptivity test }\end{array}$ & Cubes (100X100X100) & $\begin{array}{l}\text { ASTM } \\
\text { C642-2006 }\end{array}$ \\
\hline Acid attack & Cubes (100X100X100) & $\begin{array}{l}\text { ASTM } \\
\text { C1012-04, and } \\
\text { ASTM C563-07 }\end{array}$ \\
\hline
\end{tabular}

\subsubsection{Chloride ion Identification Tests}

\subsubsection{Bulk Diffusion Test}

According to ASTM C1556, the penetration depth of chloride ion and coefficient of chloride ion diffusion is calculated by bulk diffusion testing. Cylindrical specimens of size $100 \mathrm{~mm}$ in diameter and $200 \mathrm{~mm}$ high were casted and cured for 28days to attain the strength and were later kept soaked in $3.5 \%$ sodium chloride $(\mathrm{NaCl})$ solution for a duration of 35days [28]. Specimens undergo mechanical failure using compression testing machine and surface on the split side is sprayed with $0.1 \mathrm{M}$ silver Nitrate $\left(\mathrm{AgNO}_{3}\right)$ solution to quantify severity of chloride attack. After the spraying, the surface attacked by the chloride ions shows a difference in colour (white colour layer). The diffusion coefficient is determined from the chloride ion penetration depth $\left(\mathrm{X}_{\mathrm{D}}\right)$ using the following equation (4) [18].

$$
X_{D}=4 \sqrt{D} t
$$

Where $\mathrm{T}$ is the $\mathrm{NaCl}$ exposure duration

$\mathrm{D}$ is the coefficient of diffusion.

\subsubsection{Rapid Chloride Penetration Test}

As per ASTM, RCPT is done by slicing off a specimen of thickness $50 \mathrm{~mm}$ and diameter of $100 \mathrm{~mm}$ with a specimen that was $50 \mathrm{~mm}$ thick and $100 \mathrm{~mm}$ in diameter from the top portion of a cylindrical specimen casted with a diameter of $100 \mathrm{~mm}$ and a height of $200 \mathrm{~mm}$. For each mixture, three samples were made. Between the Plexiglas cells, the specimen was inserted. The anolyte solution fills the left-hand side cell. The concentration of $\mathrm{NaOH}$ was kept at $0.3 \mathrm{~N}$, and the catholyte solution $\mathrm{NaCl}$ with a concentration of $3 \%$ was employed on the other side. A $60 \mathrm{~V}$ DC power supply was used to power the cells. For 6 hours, the current was monitored at 30-minute intervals.

\section{Results and Discussions}

\subsection{Compression Test}

Compressive strength values for all three types of fiber induced concrete are shown in Figure 2. Concrete with steel fibers have shown an increase in compressive strength around $16.95 \%$, after curing for 91 days at a steel fiber volume of about $1.75 \%$. From Figure 2, it is evident that with the increase in fiber content compressive strength values also increased. It's possible that this is due to the usage of discrete fibers in concrete that are randomly dispersed[30]. Further increase in volume fraction (2\%) reduces compressive strength. When glass fibers were added into concrete, compressive strength increases about $11 \%$ at GF volume of about $1.0 \%$ for a curing period of 91 days when compared with control concrete. Compressive strength starts decreasing at a further increase of fiber volume fraction. This may be due to improper fiber dispersion. A decrease in fresh density with an increase in GF volume fraction may also result in reduction in compressive strength[7], whereas compressive strength increases at a dosage of $1.25 \%$ of EWEWCF fiber. Further increases of EWEWCF fiber content reduce the compressive strength (Figure 2). 


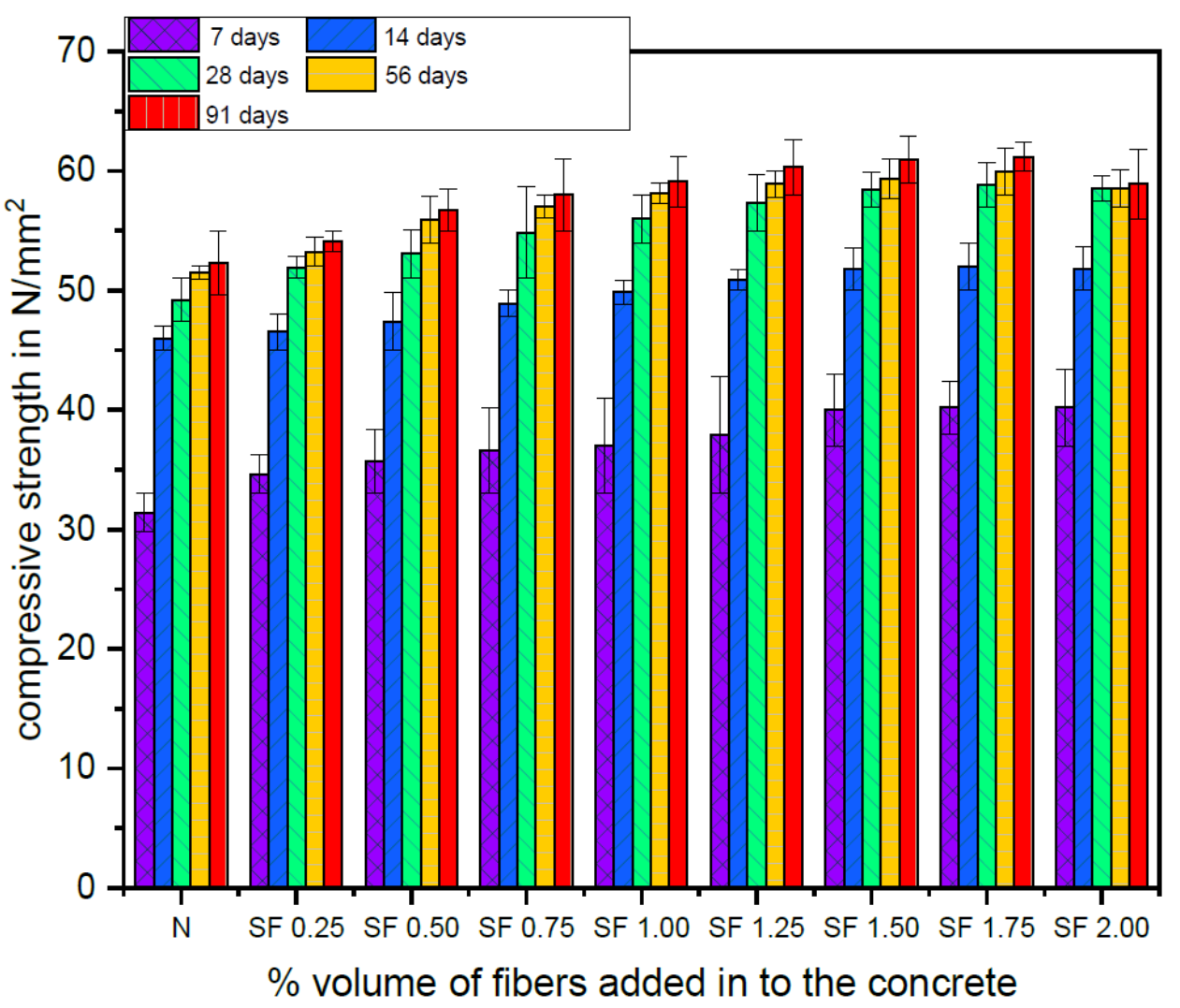

(a)

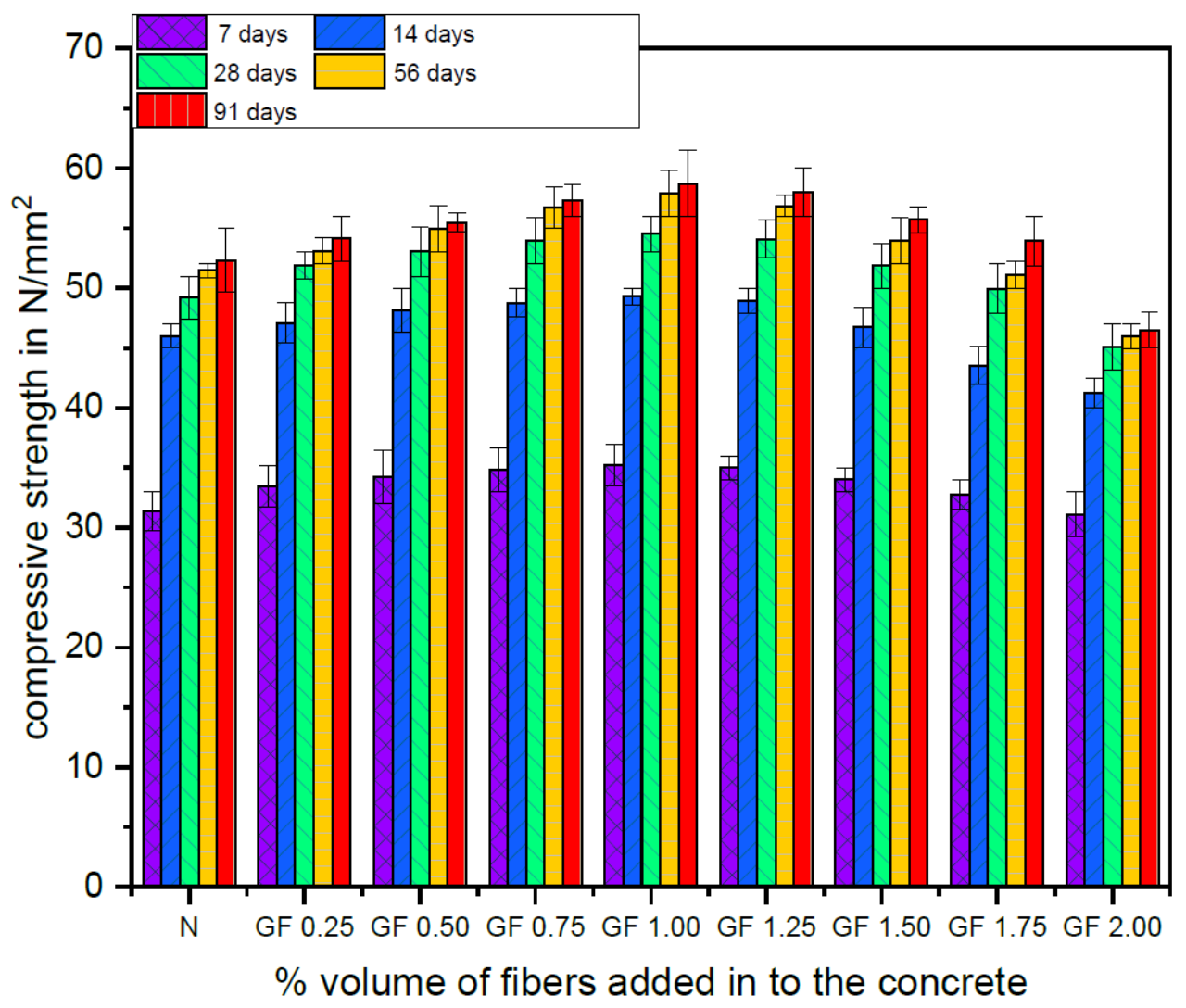

(b) 


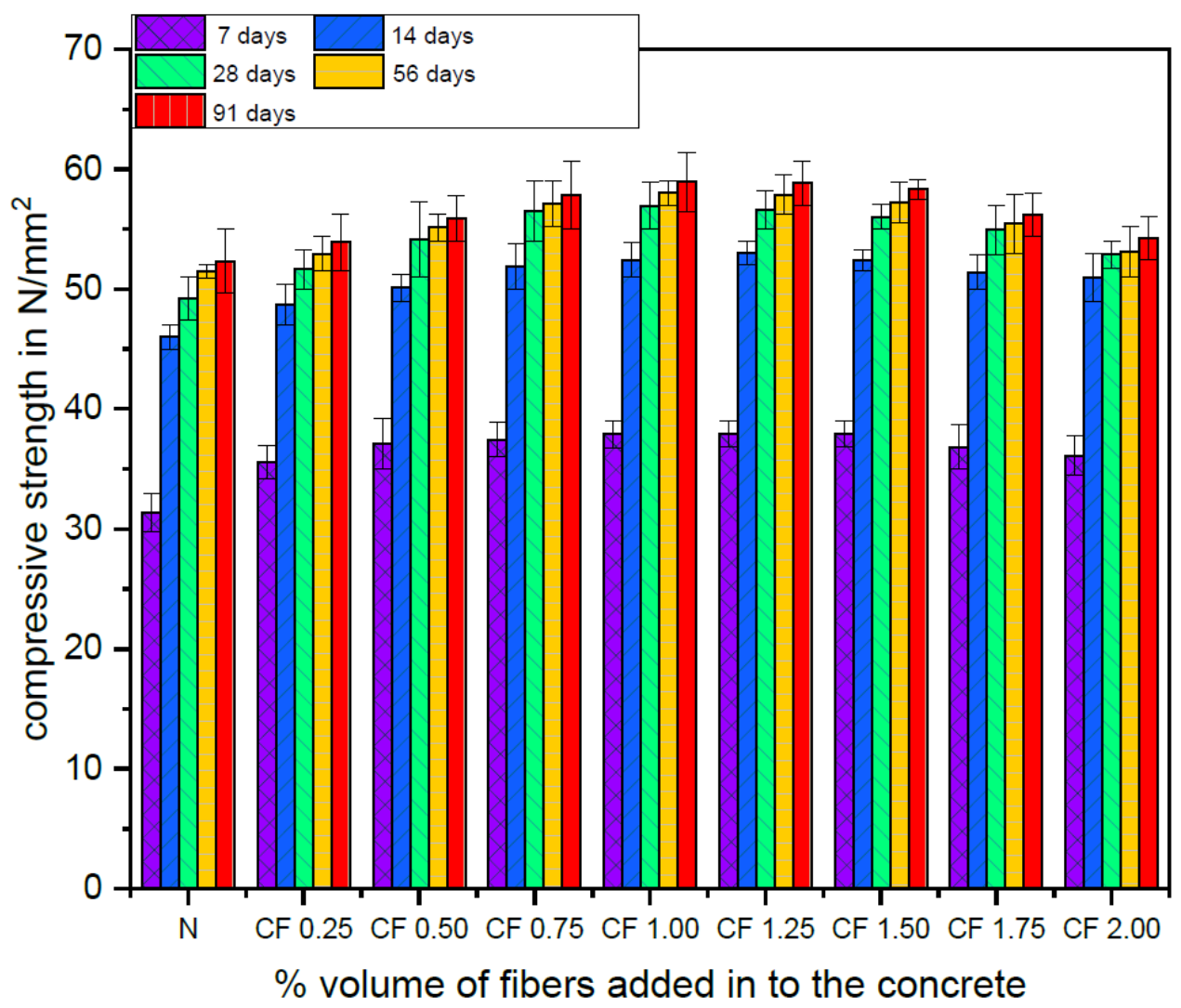

(C)

Figure 2.Compressive strength values of (a) Steel fiber (b) Glass Fiber (c) Electric copper waste fibers induced into concrete for different durations

\subsection{Split Tensile Test}

Figure 4 illustrates the split tensile strength of concrete incorporated with SF, GF and EWEWCF for different durations.

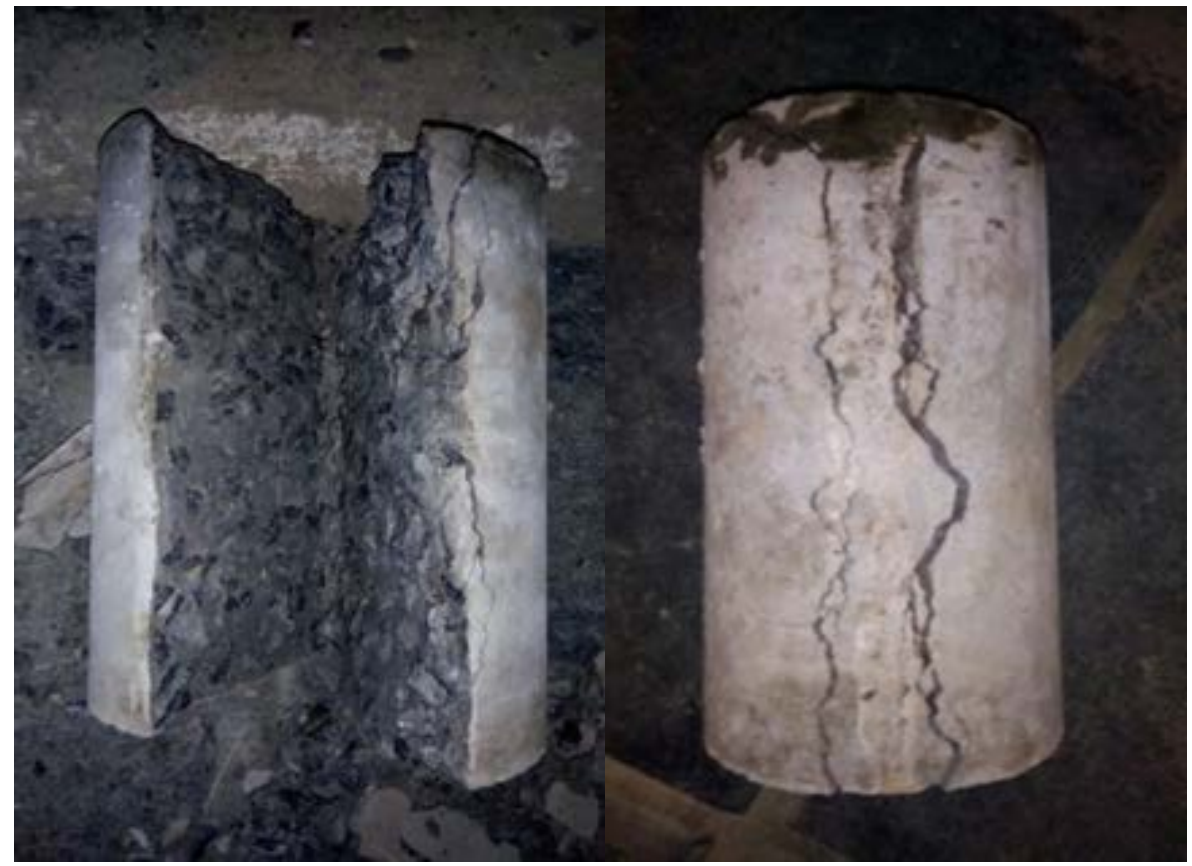

Figure 3.Failure pattern of specimen (a) Without Fibers (b) With fibers 
Different fiber orientation did not give a reliable evaluation of the split tensile strength [31]. However, the failure crack pattern can be identified. Figure 3 illustrates that the specimen of reinforced concrete did not separate after failure of the fiber.

The fiber-reinforced concrete result shows that the inclusion of fibers, particularly GF, had a significant influence on the concrete split tensile strength. When glass fibers were added into concrete, split tensile strength increases about $25.6 \%$ at GF volume of about $1.0 \%$ for curing 91 days when compared with control concrete. It may be because GF was very short-term in length, which makes the matrix stronger and concrete remained intact even after failure loading due to the substantial mechanical interlocking behavior in a fiber-reinforced concrete cylinder [32]. Split tensile strength decreases when the fiber fraction increased further (Figure 4). It may be due to the high dosage of fiber that creates a balling effect and reduces the split tensile strength[33] and the split tensile strength increases to $18.21 \%$ with a $1.25 \%$ EWCF incorporation. Tensile strength increases upon the increase of EWCF up to 1.25\%. When steel fibers (SF) are added into the concrete, split tensile strength increases about $24.33 \%$ at steel fiber volume of about $1.75 \%$ for a curing period of 91 days. Further improvement of dosage of SF has no significant changes in the split tensile strength.

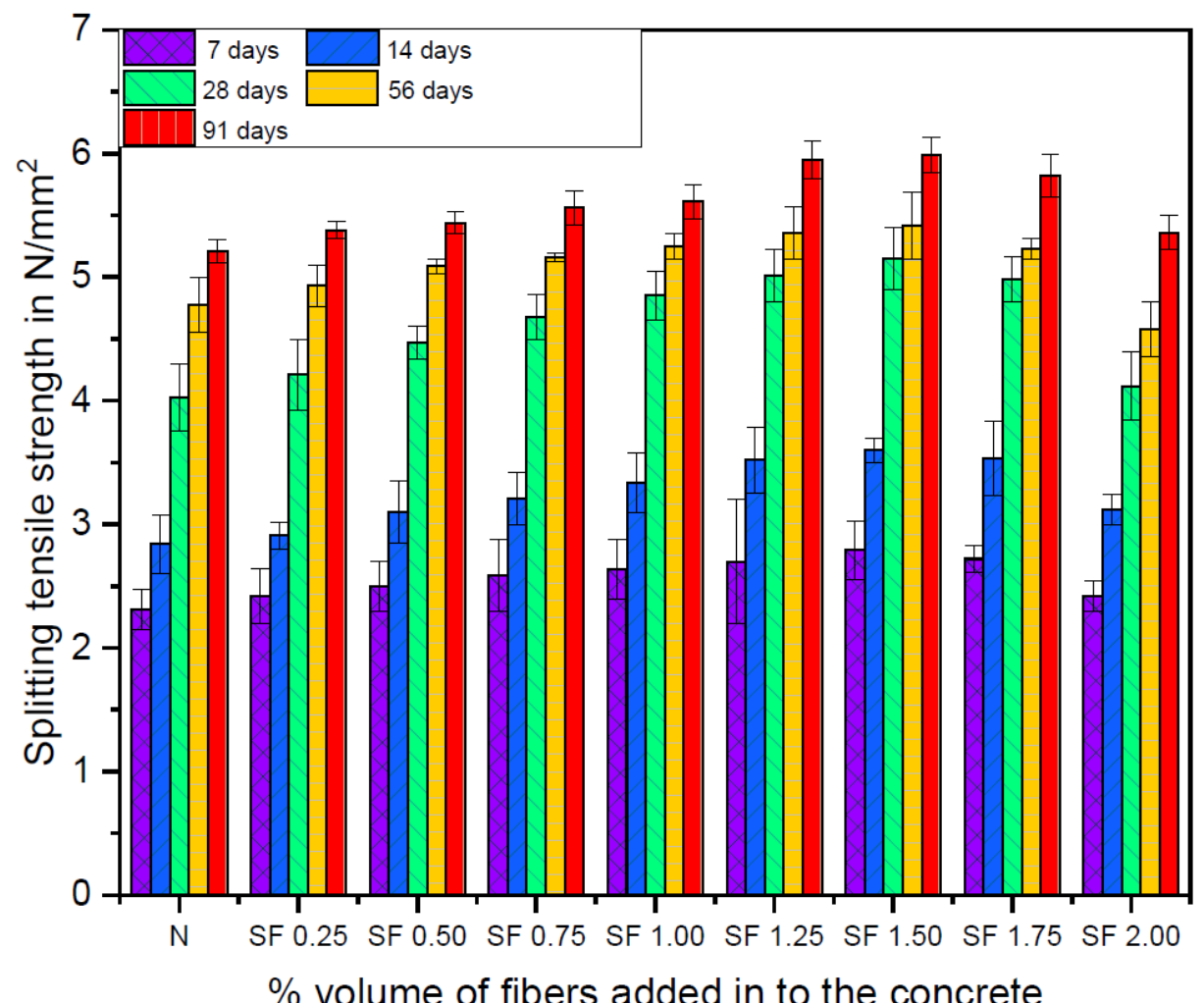




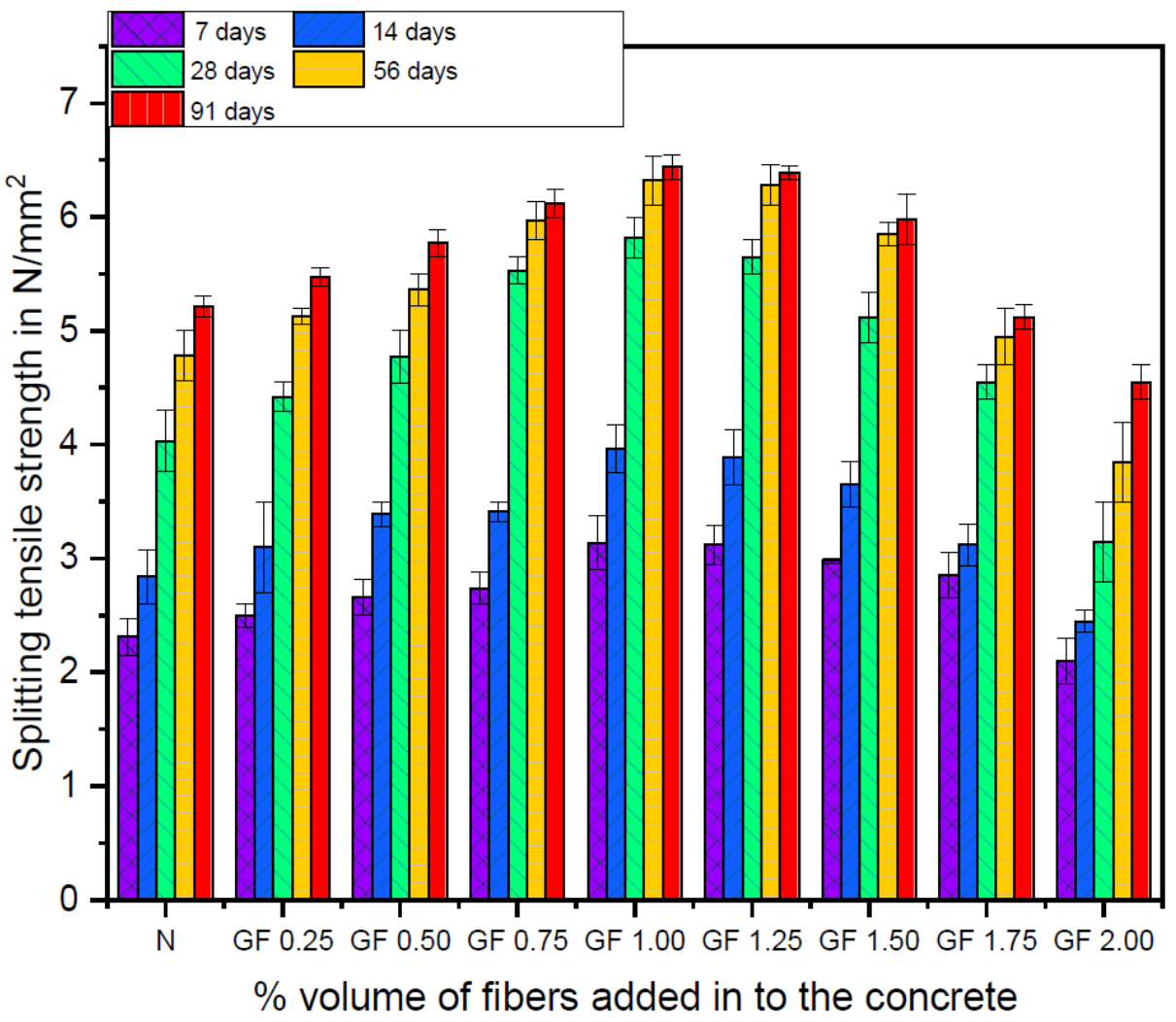

(b)

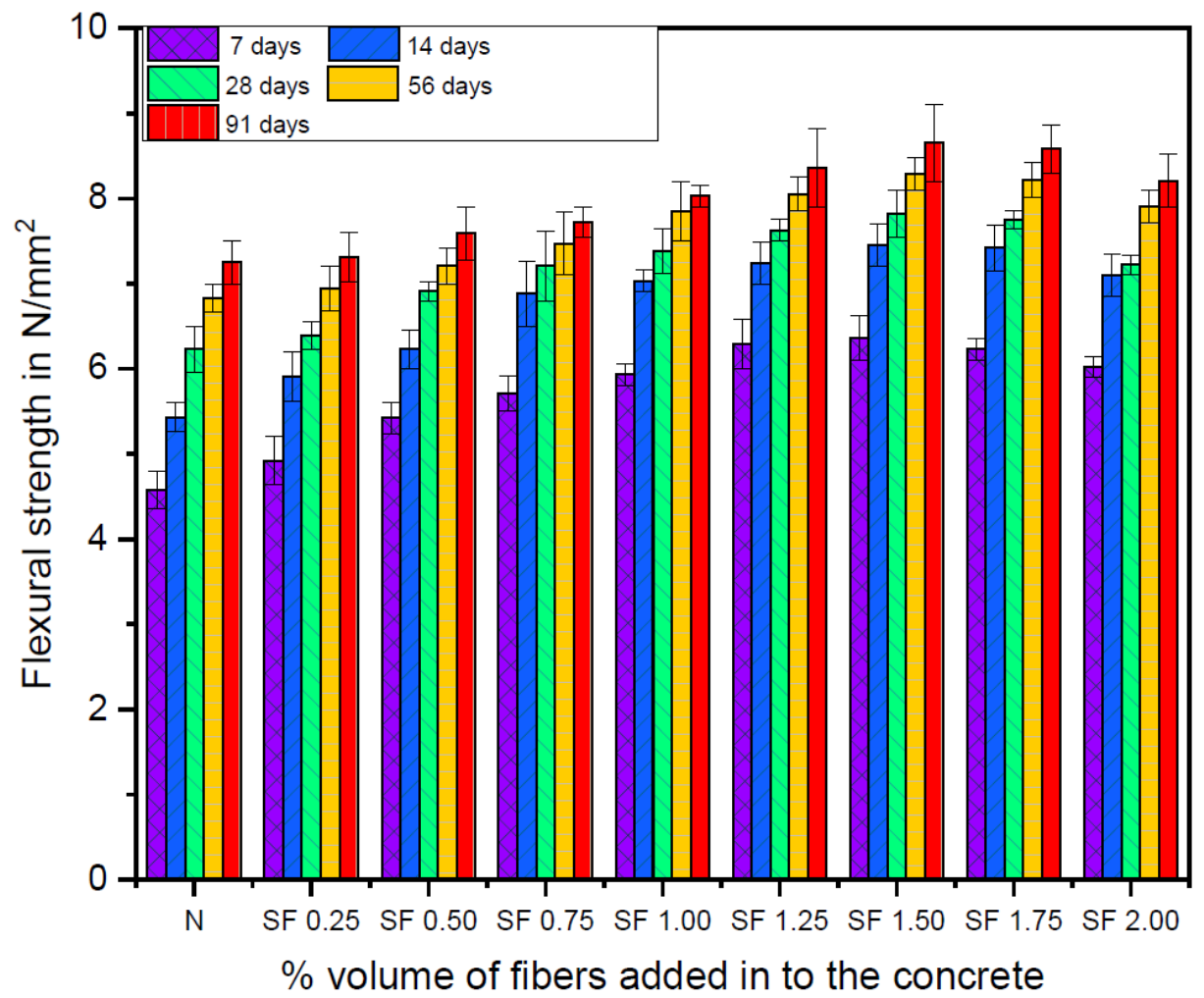

(c)

Figure 4. Split Tensile Strength of concrete induced with (a) Steel Fibers (b) Glass Fibers and (c) Electric Waste Copper Fibers

\subsection{Flexural Test}

Flexural strength results were shown in Figure 5. GF, SF and EWCF reinforced concrete give high flexural strength 
at $1 \%, 1.5 \%$, and $1.25 \%$ volume of fibers added into the concrete. SF increases flexural strength from $15.6 \%$ to $42.36 \%$, GF increases flexural strength from $9.1 \%$ to $32.13 \%$ and EWCF increases flexural strength from $11.1 \%$ to $34.07 \%$ at a curing period 91 days as shown in Figure 5. SF gives good result when compared to EWCF and GF. Further increase of the fiber content reduces the flexural strength [34].

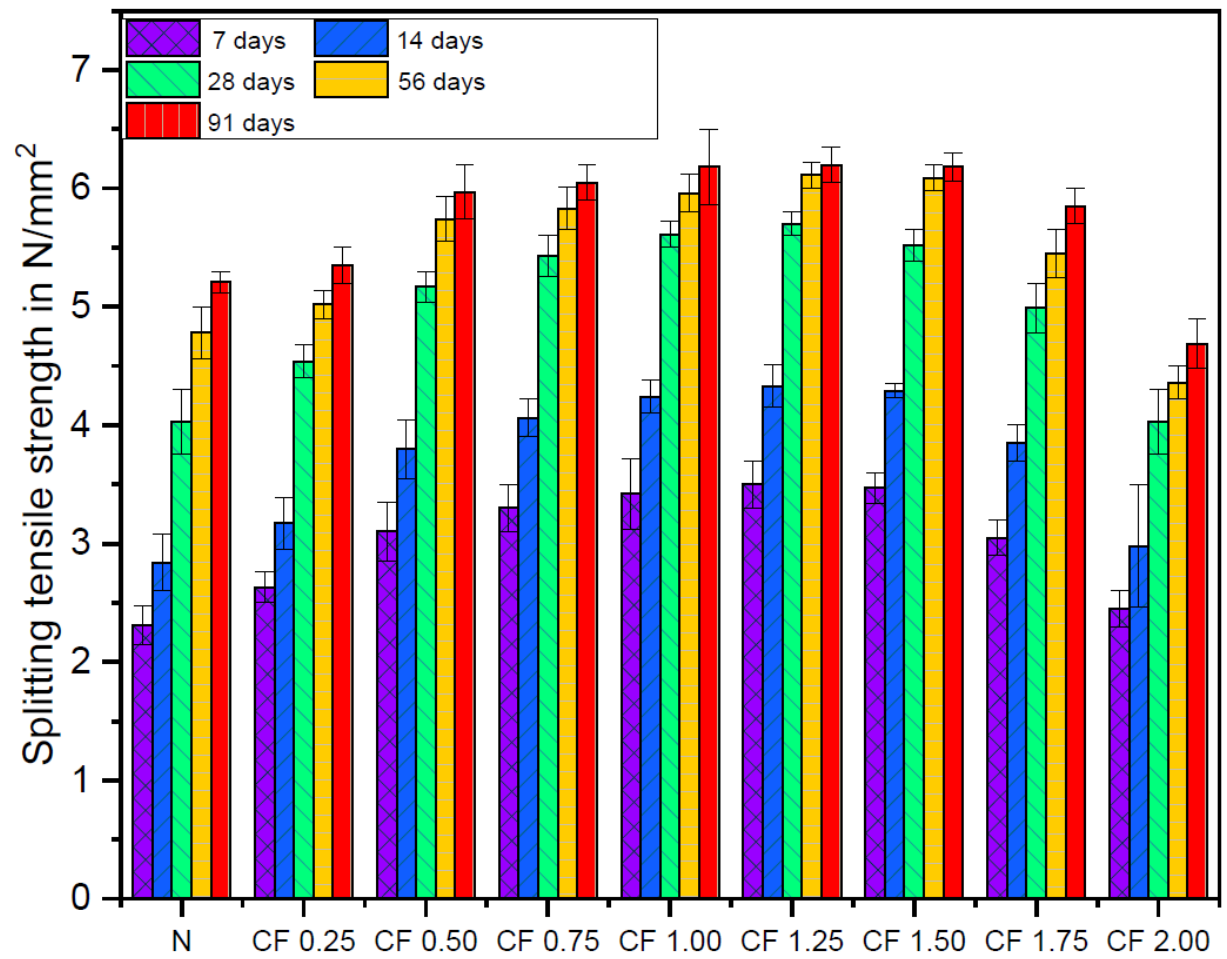

$\%$ volume of fibers added in to the concrete

(a)

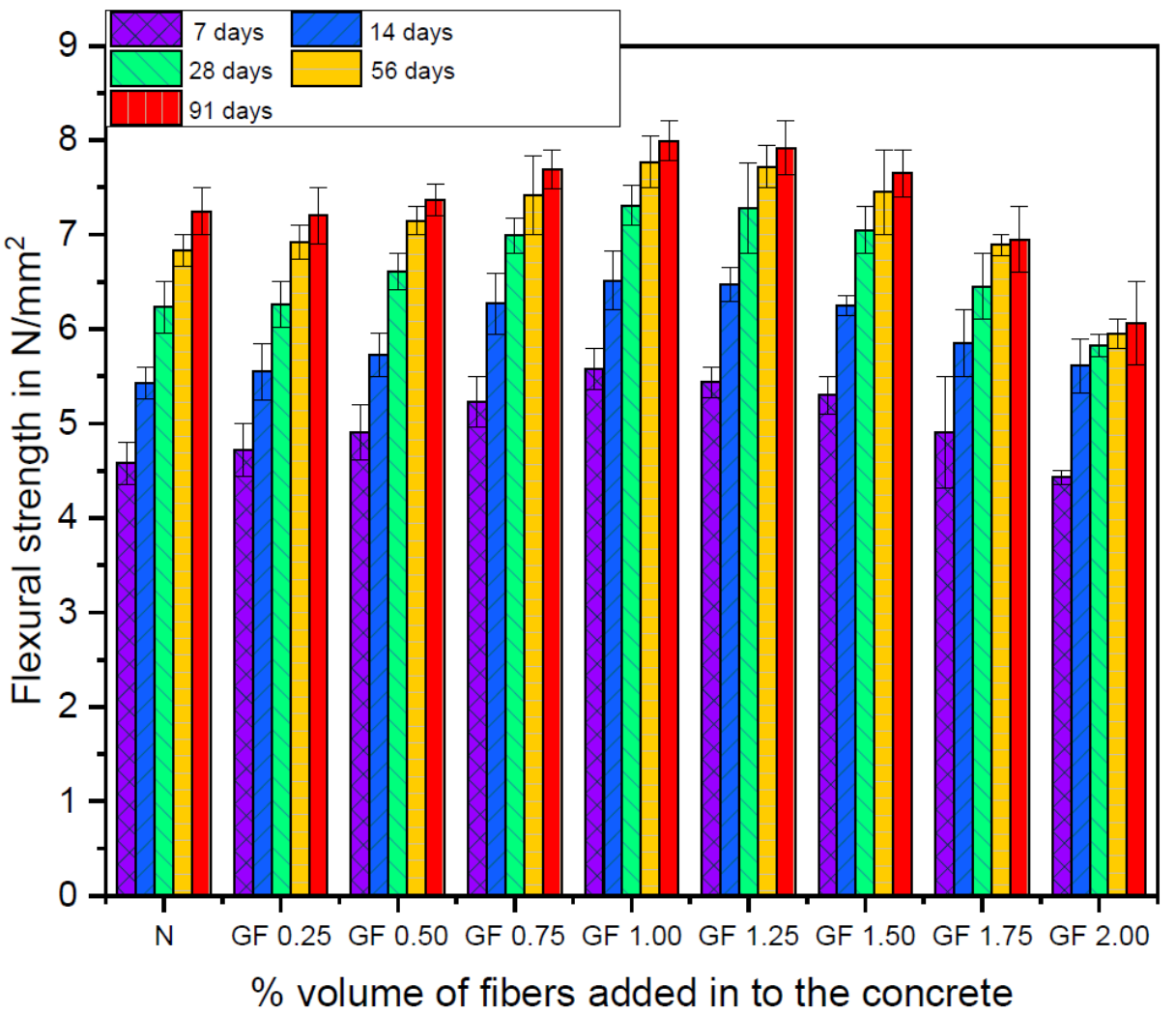

(b) 


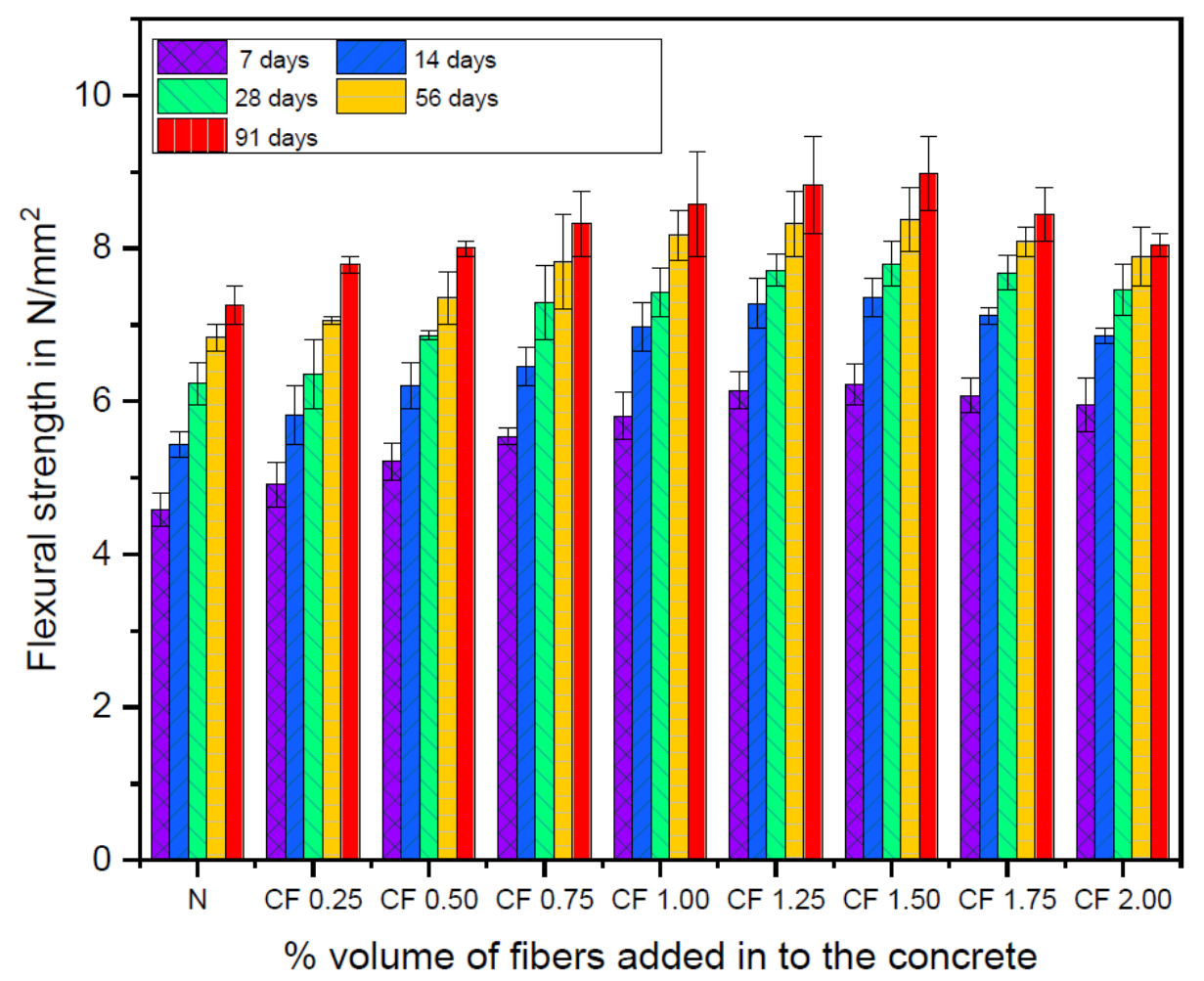

(c)

Figure 5.Flexural Strength of concrete induced with (a) Steel Fibers (b) Glass Fibers (c) Electric Waste Copper Fibers

\subsection{Modulus of Elasticity}

The elasticity modulus has been altogether improved by the expansion of fibers in concrete [35]. Curing for a period of 28 days samples, were tested as per ASTM C469-02, and the result was shown in Figure 6. At an optimum dosage, $1.25 \%$ of SF incorporate into the concrete modulus of elasticity was increased by $9.2 \%$ compared to conventional concrete. With the addition of SF, there is a slight decrement in elastic modulus values and $1 \%$ of the EWCF dosage has increased elastic modulus of concrete by $5.1 \%$ compared to conventional concrete $(\mathrm{N})$. When $1.0 \%$ dosage of the GF is added in concrete there is no significant effect on modulus of elasticity as shown in Figure 6.

\subsection{Water Absorption and Sorptivity Test}

Diffusion and capillary activity are essential processes for moving chloride and sulphate ions into the concrete. Diffusion alone was a prolonged process. The initial absorption value for control concrete and fiber-reinforced concrete was observed at 30 minutes, and the final absorption value at 96 hours (CEB-FIP model code1990), as shown in Table 3. 


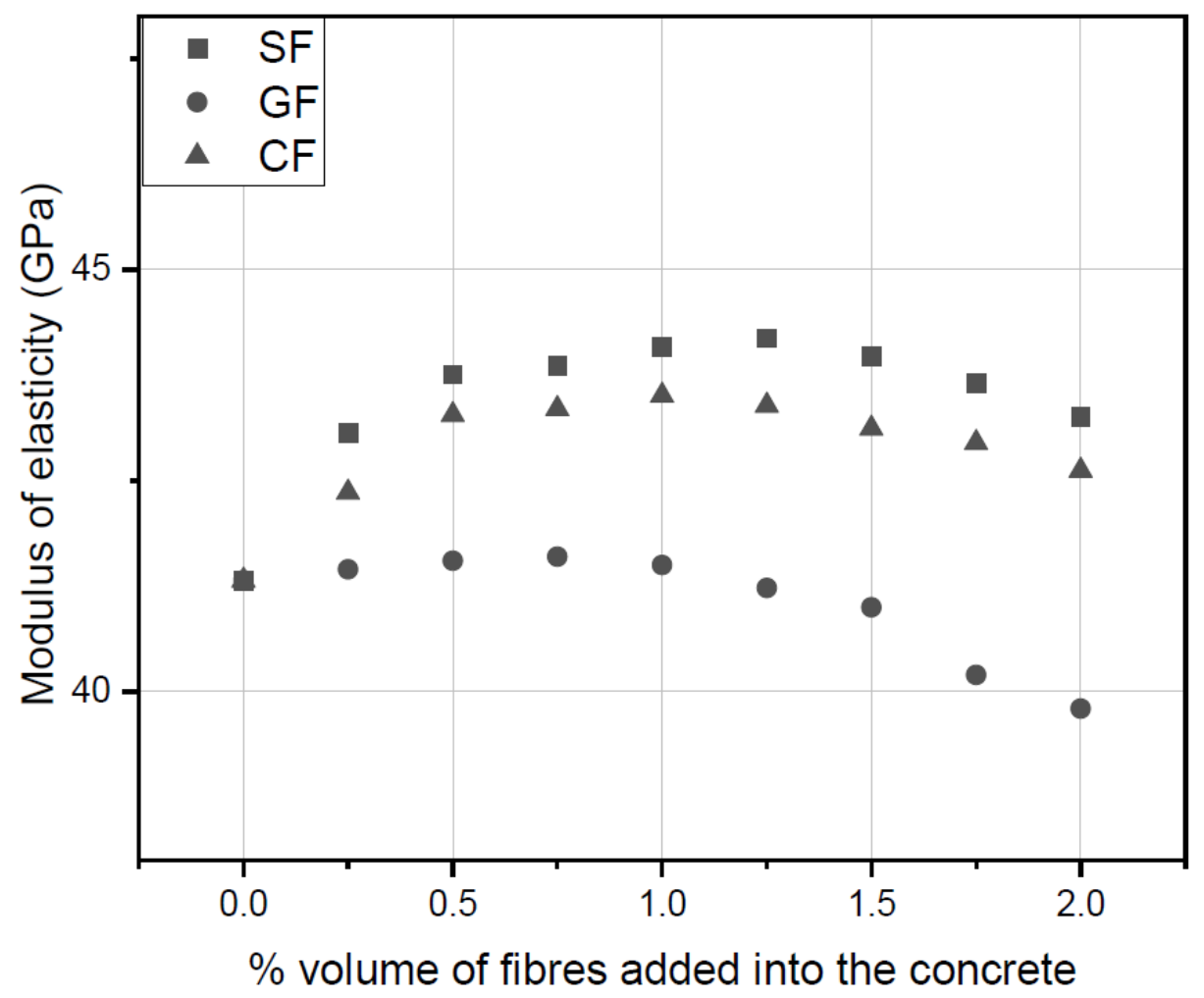

Figure 6. Modulus of Elasticity of fiber induced concrete

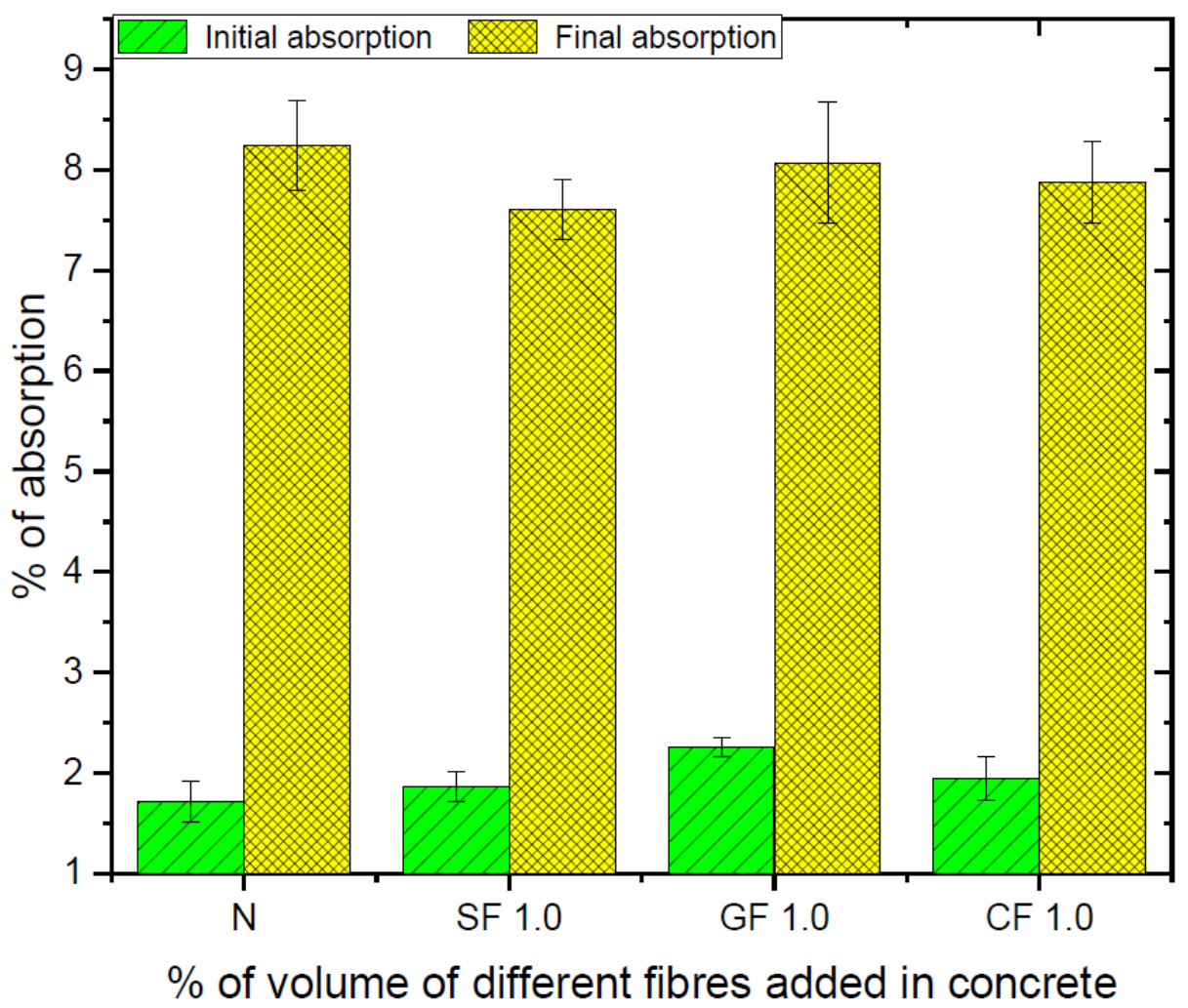

Figure 7. Initial and Final water absorption of concrete with EWCF

The sorptivity of concrete can be viewed as a that absorb water into concrete [36]. The total volume of measurement of the capillary power produced by the pores capillary waters consumed in the day was determined by 
calculation by each unit area of concrete with and without fibers (Figure 7). The resulting graph could be straight line approximated, and the best fit line slope gives the sorptivity. Table 4 shows the result of the sorptivity test. It can be observed from Table 4 that the fiber reinforced concrete sorptivity values were less than control concrete. The sorptivity values of SF, GF and EWCF, was decreased by $8 \%, 14 \%$ and $12 \%$, respectively, when compared to conventional concrete $(\mathrm{N})$.

\subsection{Acid Attack}

Two sets of samples were prepared to study the effect of acid exposure on the strength of the concrete. The first set was covered in water, and the second set was covered by $5 \% \mathrm{H}_{2} \mathrm{SO}_{4}$ solution. Specimens held at $5 \% \mathrm{H}_{2} \mathrm{SO}_{4}$ on the 28th, 56th and 91st days were determined to achieve short- and long-term performance. Each specimen weight and compressive strength were determined and modifications based on the first scenario were computed after drying under laboratory conditions as shown in Table 5.In the first set of samples (cured in water) compared to the second set of samples (cured in acid), the strength and weight loss of conventional concrete was $49.41 \%$ and $26.37 \%$ at 91 days. When GF, EWCF and SF incorporated into the concrete and then the first set of samples compared to the second set of samples, the weight loss of the samples was $24.56 \%, 25.71 \%$ and $25.84 \%$ at 91 days and strength loss of samples were $44.55 \%, 47.84 \%$ and $47.92 \%$. These results have clearly shown GF reinforced concrete performance was better than the SF and EWCF. Finally, Figure 8 Clearly exhibits fiber reinforced concrete has better chemical resistance compared to conventional concrete $(\mathrm{N})$. It may be due to the fibers were added in concrete to increase concrete toughness and density [37].

Table 3. Results of Water absorption and Porosity

\begin{tabular}{|c|c|c|c|c|c|c|c|c|}
\hline MIX ID & $\begin{array}{l}\text { W1 } \\
\text { (Kg) }\end{array}$ & $\begin{array}{l}\text { W2 } \\
\text { (Kg) }\end{array}$ & $\begin{array}{l}\text { W3 } \\
\text { (Kg) }\end{array}$ & $\begin{array}{c}\text { Initial absorption } \\
\frac{\left(W_{2}-W_{1}\right)}{W_{1}} \times 100 \\
(\%)\end{array}$ & $\begin{array}{l}\text { Final absorption } \\
\frac{\left(W_{3}-W_{1}\right)}{W_{1}} \times 100 \\
(\%)\end{array}$ & $\begin{array}{l}\text { Quality of } \\
\text { concrete }\end{array}$ & $\begin{array}{c}\text { Void's } \\
\text { Volume } \\
\left(\mathrm{cm}^{3}\right)\end{array}$ & $\begin{array}{c}\text { Effective } \\
\text { porosity } \\
\text { Average value } \\
(\%)\end{array}$ \\
\hline $\mathrm{N}$ & 2.39 & 2.431 & 2.587 & 1.715 & 8.243 & Good & 197 & 19.7 \\
\hline SF 1.0 & 2.407 & 2.452 & 2.501 & 1.870 & 7.603 & Good & 183 & 18.3 \\
\hline GF 1.0 & 2.391 & 2.445 & 2.584 & 2.258 & 8.072 & Good & 193 & 19.3 \\
\hline EWCF 1.0 & 2.412 & 2.459 & 2.602 & 1.949 & 7.877 & Good & 190 & 19 \\
\hline
\end{tabular}

Table 4. Results of sorptivity

\begin{tabular}{|c|c|c|c|c|c|c|c|c|c|}
\hline \multirow{2}{*}{ Mix ID } & \multicolumn{4}{|c|}{$\begin{array}{c}\text { The cumulative weight of water penetrated } \\
\text { in grams after immersing in water }\end{array}$} & \multicolumn{3}{|c|}{$\begin{array}{c}\text { The cumulative volume of water } \\
\text { penetrated/surface area of exposure (cm) }\end{array}$} & \multicolumn{2}{c|}{$\begin{array}{c}\text { Sorptivity } \\
\left(\mathbf{c m} / \mathbf{m i n}^{\mathbf{1 / 2}}\right) \times \mathbf{1 0}^{-3}\end{array}$} \\
\hline & $30 \mathrm{~min}$ & $60 \mathrm{~min}$ & $90 \mathrm{~min}$ & $120 \mathrm{~min}$ & $30 \mathrm{~min}$ & $60 \mathrm{~min}$ & $90 \mathrm{~min}$ & $120 \mathrm{~min}$ & 7.71 \\
\hline N & 9 & 10.65 & 14.73 & 16.45 & 0.09 & 0.11 & 0.15 & 0.16 & 7.09 \\
\hline SF 1.0 & 8.6 & 9.75 & 13.12 & 15.32 & 0.09 & 0.1 & 0.13 & 0.15 & 5.91 \\
\hline GF 1.0 & 7.15 & 7.83 & 10.5 & 12.56 & 0.07 & 0.08 & 0.11 & 0.13 & 6.75 \\
\hline EWCF 1.0 & 8.75 & 9.32 & 12.95 & 14.92 & 0.09 & 0.1 & 0.13 & 0.15 & \\
\hline
\end{tabular}

Table 5. Results of Acid Attack

\begin{tabular}{|c|c|c|c|c|c|c|}
\hline \multirow{2}{*}{ Mix ID } & \multicolumn{3}{|c|}{ \% weight loss } & \multicolumn{3}{c|}{ \% loss in compressive strength } \\
\cline { 2 - 7 } & 28 days & 56 days & 91 days & 28 days & 56 days & 91 days \\
\hline N & -3.25 & -11.12 & -26.37 & -12.4 & -23.72 & -49.41 \\
\hline SF 1.0 & -4.44 & -13.22 & -25.84 & -10.73 & -21.3 & -47.92 \\
\hline GF 1.0 & -3.67 & -12.09 & -24.56 & -8.9 & -20.9 & -44.55 \\
\hline EWCF 1.0 & -4.79 & -12.97 & -25.71 & -11.1 & -23.12 & -47.84 \\
\hline
\end{tabular}




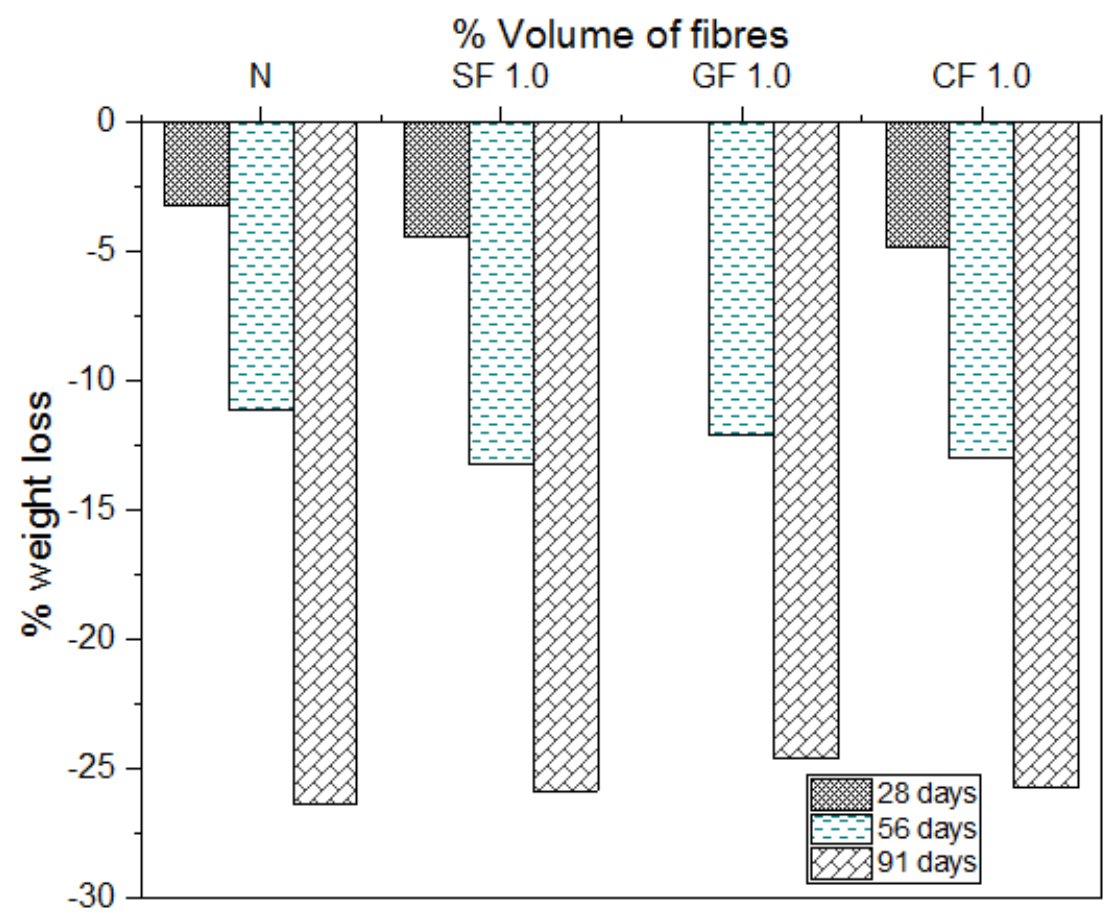

(a)

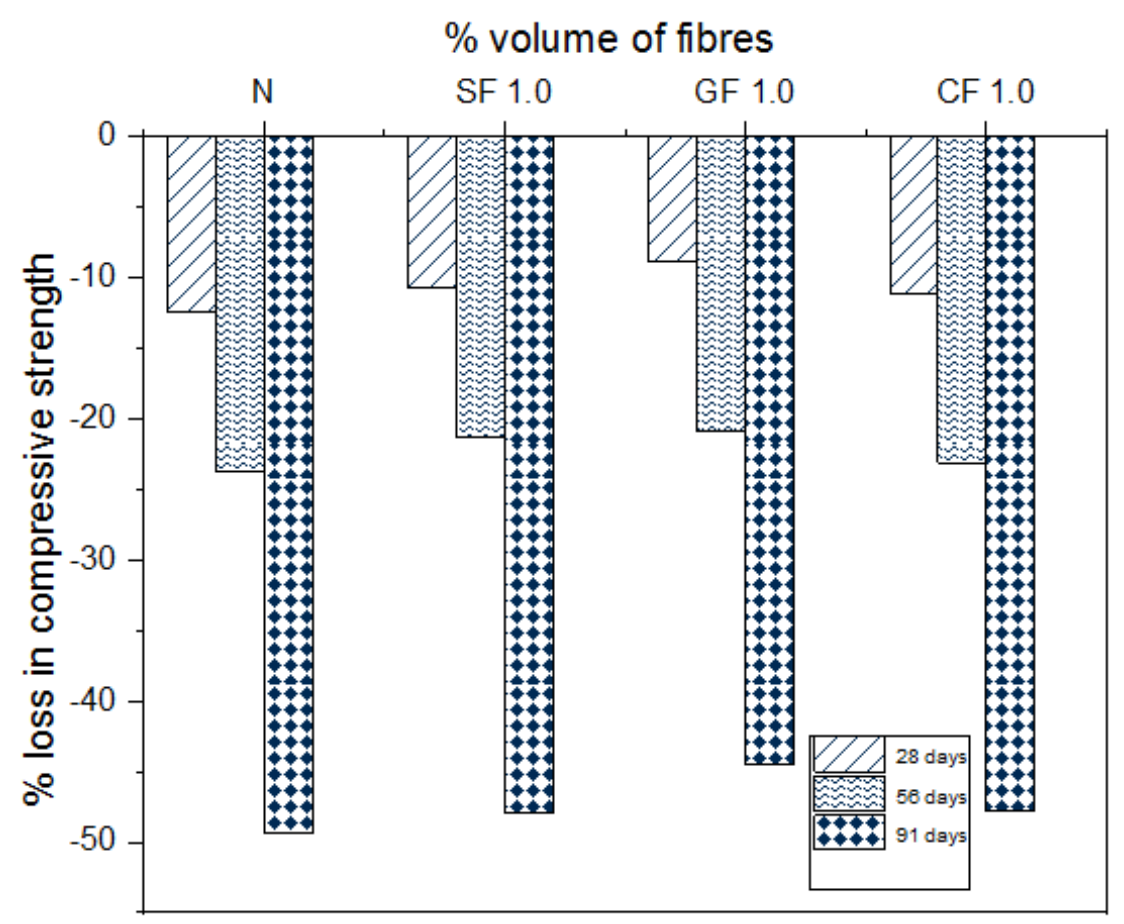

(b)

Figure 8.Percentage loss in (a) Weight (b) Compressive strength of the specimen

\subsection{Bulk Diffusion and Chloride Penetration Test}

The depth of the chloride ion penetration of concrete specimens was given in Table 6. When 1\% SF, GF and EWCF was incorporated into the concrete, the chloride penetration depth was reduced by $2 \%, 4.4 \%$ and $1.2 \%$ in comparison with conventional concrete. This can be because the addition of fibers reduces the void volume and lowers the concrete porosity[38]. But the opposite trend was observed in the rapid chloride permeability test. SF and EWCF incorporate into the concrete increase the charge passed through the specimens at all ages of 
concrete mix (Table 6). GF inclusion into the concrete significantly reduces the charge pass through the concrete at all ages. The reason for this may be the SF and EWCF are good conductor of electricity[39].

Table 6. Results of RCPT and Bulk diffusion Test

\begin{tabular}{|c|c|c|c|c|}
\hline Mix ID & $\begin{array}{c}\text { Chloride } \\
\text { ion } \\
\text { penetration } \\
\text { depth (cm) }\end{array}$ & $\begin{array}{c}\text { Coefficient } \\
\text { of } \\
\text { diffusion } \\
\left(\mathbf{m}^{2} / \mathbf{s}\right)\end{array}$ & $\begin{array}{c}\text { The } \\
\text { charge } \\
\text { passed } \\
\text { (C) }\end{array}$ & $\begin{array}{c}\text { As per } \\
\text { ASTM } \\
\text { standard } \\
\text { Chloride } \\
\text { ion } \\
\text { penetration } \\
\text { depth }\end{array}$ \\
\hline R & 2.5 & $1.29 \times 10^{-11}$ & 1764 & low \\
\hline SF 1.0 & 2.45 & $1.24 \times 10^{-11}$ & 1782 & low \\
\hline GF 1.0 & 2.39 & $1.18 \times 10^{-11}$ & 1423 & low \\
\hline EWCF 1.0 & 2.47 & $1.26 \times 10^{-11}$ & 1790 & low \\
\hline
\end{tabular}

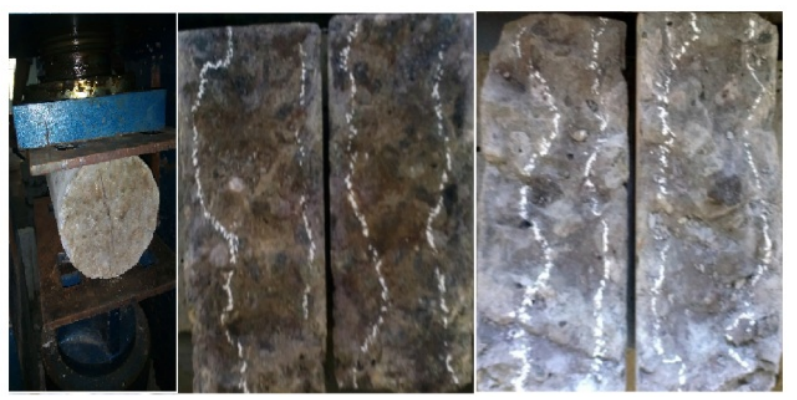

Figure 8. Pattern of chloride ion diffusion on failed sample

\section{Conclusions}

The following conclusions were derived from the work.

1. Electrical waste fibers incorporated concrete mixes to enhance the mechanical and durability properties compared to conventional concrete.

2. When EWCF fibers used mixes showed increased mechanical properties and durability properties than the conventional concrete mixes.

3. SF added concrete mixes showed an excellent result of compressive strength, flexural strength and modulus of elasticity than the mixes containing GF and EWCF.

4. When GF inclusion in concrete mixes showed better flexural strength than the SF and EWCF incorporated mixes but not significantly increase the modulus of elasticity of the concrete. More than 1\% of GF added in concrete modulus of elasticity drastically decreased.

5. Water absorption and sorptivity characteristics of the mix were found to be reduced with the addition of fibers. SF inclusion concrete mix gives a better result than the mixes containing GF and EWCF.

6. Acid resistance of concrete was observed to be increased with fibers(SF, GF \& EWCF) incorporated in the mixes. GF performed well than the other mixes.
7. Chloride ion permeability depth and bulk diffusion coefficients of fiber reinforced concrete mixes were less than that of conventional concrete mixes, but the opposite trend was observed in the rapid chloride penetration test. In this experiment, fibers incorporated into the concrete charge passing through the specimen were increased. Only GF inclusion concrete mixes performance was better than the conventional concrete mix.

\section{REFERENCES}

[1] A. Sofi and G. Naidu Gopu, "Influence of steel fiber, electrical waste copper wire fiber and electrical waste glass fiber on mechanical properties of concrete," in IOP Conference Series: Materials Science and Engineering, 2019, vol. 513, no. 1, doi:

10.1088/1757-899X/513/1/012023.

[2] T. Simões, H. Costa, D. Dias-da-Costa, and E. Júlio, "Influence of fibers on the mechanical behaviour of fiber reinforced concrete matrixes," Constr. Build. Mater., vol. 137, pp. 548-556, Apr. 2017, doi:10.1016/J.CONBUILDMAT.2017.01.104.

[3] P. Kittl, E. Galleguillos, and G. Diaz, "Properties of compacted copper fiber reinforced cement composite," Int. J. Cem. Compos. Light. Concr., vol. 7, no. 3, pp. 193-197, Aug. 1985, doi: 10.1016/0262-5075(85)90007-7.

[4] J. Thomas, N. N. Thaickavila, and M. P. Abrahamb, "Copper or ferrous slag as substitutes for fine aggregates in concrete,” Adv. Concr. Constr., vol. 6, no. 5, pp. 545-560, 2018, doi: 10.12989/acc.2018.6.5.545.

[5] V. Afroughsabet and T. Ozbakkaloglu, "Mechanical and durability properties of high-strengsth concrete containing steel and polypropylene fibers," Constr. Build. Mater., vol. 94, pp. 73-82, Sep. 2015, doi:

10.1016/J.CONBUILDMAT.2015.06.051.

[6] A. Alsaif, S. A. Bernal, M. Guadagnini, and K. Pilakoutas, "Durability of steel fiber reinforced rubberised concrete exposed to chlorides," Constr. Build. Mater., vol. 188, pp. 130-142, 2018, doi: 10.1016/j.conbuildmat.2018.08.122.

[7] C. H. Chen, R. Huang, J. K. Wu, and C. C. Yang, "Waste E-glass particles used in cementitious mixtures," Cem. Concr. Res., vol. 36, no. 3, pp. 449-456, Mar. 2006, doi: 10.1016/J.CEMCONRES.2005.12.010.

[8] S. A. Zareei, F. Ameri, N. Bahrami, P. Shoaei, H. R. Musaeei, and F. Nurian, "Green high strength concrete containing recycled waste ceramic aggregates and waste carpet fibers: Mechanical, durability, and microstructural properties,” J. Build. Eng., vol. 26, p. 100914, Nov. 2019, doi: 10.1016/J.JOBE.2019.100914.

[9] M. S. Midhun, T. D. Gunneswara Rao, and T. Chaitanya Srikrishna, "Mechanical and fracture properties of glass fiber reinforced geopolymer concrete," Adv. Concr. Constr., vol. 6, no. 1, pp. 29-45, 2018, doi: 10.12989/acc.2018.6.1.029. 
[10] A. B. Kizilkanat, N. Kabay, V. Akyüncü, S. Chowdhury, and A. H. Akça, "Mechanical properties and fracture behavior of basalt and glass fiber reinforced concrete: An experimental study,” Constr. Build. Mater., vol. 100, pp. 218-224, Dec. 2015, doi:

10.1016/J.CONBUILDMAT.2015.10.006.

[11] M. H. Al-Majidi, A. P. Lampropoulos, A. B. Cundy, O. T. Tsioulou, and S. Alrekabi, "Flexural performance of reinforced concrete beams strengthened with fiber reinforced geopolymer concrete under accelerated corrosion,” Structures, vol. 19, pp. 394-410, Jun. 2019, doi: 10.1016/J.ISTRUC.2019.02.005.

[12] N. Ganesan, R. Sahana, and P. V. Indira, "Effect of hybrid fibers on tension stiffening of reinforced geopolymer concrete," Adv. Concr. Constr., vol. 5, no. 1, pp. 75-86, 2017, doi: 10.12989/acc.2017.5.1.75.

[13] F. Grzymski, M. Musiał, and T. Trapko, "Mechanical properties of fiber reinforced concrete with recycled fibers," Constr. Build. Mater., vol. 198, pp. 323-331, Feb. 2019, doi: 10.1016/J.CONBUILDMAT.2018.11.183.

[14] C. G. Berrocal, K. Lundgren, and I. Löfgren, "Corrosion of steel bars embedded in fiber reinforced concrete under chloride attack: State of the art,” Cem. Concr. Res., vol. 80, pp. 69-85, Feb. 2016, doi:

10.1016/J.CEMCONRES.2015.10.006.

[15] J. P. Hwang, M. S. Jung, M. Kim, and K. Y. Ann, "Corrosion risk of steel fiber in concrete," Constr. Build. Mater., vol. 101, pp. 239-245, Dec. 2015, doi: 10.1016/J.CONBUILDMAT.2015.10.072.

[16] P. R. Kalyana Chakravarthy, T. Ilango, and S. Chezhiyan, "A detailed study on the mechanical and durability properties of hybrid fiber reinforced concrete," Mater. Today Proc., Aug. 2019, doi:10.1016/J.MATPR.2019.06.739.

[17] V. Marcos-Meson, G. Fischer, C. Edvardsen, T. L. Skovhus, and A. Michel, "Durability of Steel Fiber Reinforced Concrete (SFRC) exposed to acid attack - A literature review," Constr. Build. Mater., vol. 200, pp. 490-501, Mar. 2019, doi: 10.1016/J.CONBUILDMAT.2018.12.051.

[18] N. Ganesan, R. Abraham, and S. Deepa Raj, "Durability characteristics of steel fiber reinforced geopolymer concrete,” Constr. Build. Mater., vol. 93, pp. 471-476, Sep. 2015, doi: 10.1016/J.CONBUILDMAT.2015.06.014.

[19] K. Tang, "Corrosion of steel fiber reinforced concrete (SFRC) subjected to simulated stray direct (DC) interference,” Mater. Today Commun., vol. 20, p. 100564, Sep. 2019, doi: 10.1016/J.MTCOMM.2019.100564.

[20] IS:12269-2013, “ORDINARY PORTLAND CEMENT , 53 grade specification ( First Revision ),” Bur. Indian Stand. New Delhi, India, no. March, pp. 1-10, 2013.

[21] IS383-2016, “Coarse and fine aggregate for concrete," Indian Stand. Code, vol. Third edit, no. January, p. 21, 2016.

[22] BIS:10262, "Indian Standard Guidelines for concrete mix design proportioning," Bur. Indian Stand. New Delhi, p. New Delhi,India, 2009.
[23] B. R. A. Sofi and Phanikumar, "Durability properties of fiber-reinforced pond ash-modified concrete,” no. January, 2017.

[24] K. Aarthi and K. Arunachalam, "Durability studies on fiber reinforced self compacting concrete with sustainable wastes,” J. Clean. Prod., vol. 174, pp. 247-255, Feb. 2018, doi: 10.1016/J.JCLEPRO.2017.10.270.

[25] I. Fernandes, M. Pericão, P. Hagelia, F. Noronha, M. A Ribeiro, and J. Maia, "Identification of acid attack on concrete of a sewage system,” Mater. Struct. Constr., vol. 45, no. 3, pp. 337-350, 2012, doi:10.1617/s11527-011-976 9-y.

[26] D. S. Cheema, "Durability of steel in geopolymer concrete," in 18th International Corrosion Congress 2011, 2011, vol. 1, pp. 87-95.

[27] M. Nematzadeh, J. Dashti, and B. Ganjavi, "Optimizing compressive behavior of concrete containing fine recycled refractory brick aggregate together with calcium aluminate cement and polyvinyl alcohol fibers exposed to acidic environment," Constr. Build. Mater., vol. 164, pp. 837-849, 2018, doi: 10.1016/j.conbuildmat.2017.12.230.

[28] N. Ganesan, P. V. Indira, and A. Santhakumar, "Durability characteristics and compressive constitutive behaviour of steel fiber reinforced geopolymer concrete," in Proceedings of the 3rd International Conference on the Durability of Concrete Structures, ICDCS 2012, 2012.

[29] “ASTM C1202 - 19 Standard Test Method for Electrical Indication of Concrete's Ability to Resist Chloride Ion Penetration.”.

[30] T. DESAI, R. SHAH, A. PELED, and B. MOBASHER, "Mechanical Properties of Concrete Reinforced with AR-Glass Fibers,” Brittle Matrix Compos. 7, pp. 223-232, Jan. 2003, doi: 10.1533/9780857093103.223.

[31] M. Mahdikhani, O. Bamshad, and M. Fallah Shirvani, "Mechanical properties and durability of concrete specimens containing nano silica in sulfuric acid rain condition," Constr. Build. Mater., vol. 167, pp. 929-935, 2018, doi: 10.1016/j.conbuildmat.2018.01.137.

[32] M. M. Hilles and M. M. Ziara, "Mechanical behavior of high strength concrete reinforced with glass fiber," Eng. Sci. Technol. an Int. J., vol. 22, no. 3, pp. 920-928, Jun. 2019, doi: 10.1016/J.JESTCH.2019.01.003.

[33] R. de S. Castoldi, L. M. S. de Souza, and F. de Andrade Silva, "Comparative study on the mechanical behavior and durability of polypropylene and sisal fiber reinforced concretes," Constr. Build. Mater., vol. 211, pp. 617-628, Jun. 2019, doi: 10.1016/J.CONBUILDMAT.2019.03.282.

[34] D. Das, O. P. Dubey, M. Sharma, R. K. Nayak, and C. Samal, "Mechanical properties and abrasion behaviour of glass fiber reinforced polymer composites - A case study," Mater. Today Proc., vol. 19, pp. 506-511, Jan. 2019, doi: 10.1016/J.MATPR.2019.07.644.

[35] S. Ghorbani et al., "Mechanical and durability behaviour of concrete with granite waste dust as partial cement replacement under adverse exposure conditions," Constr. Build. Mater., vol. 194, pp. 143-152, 2019, doi: 10.1016/j.conbuildmat.2018.11.023. 
[36] X. Shi, N. Xie, K. Fortune, and J. Gong, "Durability of steel reinforced concrete in chloride environments: An overview," Constr. Build. Mater., vol. 30, pp. 125-138, May 2012, doi: 10.1016/J.CONBUILDMAT.2011.12.038.

[37] S. T. Tassew and A. S. Lubell, "Mechanical properties of glass fiber reinforced ceramic concrete," Constr. Build. Mater., vol. 51, pp. 215-224, 2014, doi: https://doi.org/10.1016/j.conbuildmat.2013.10.046.
[38] J. Zhang, W. Jin, J. Mao, J. Long, and X. Zhong, "Deterioration of static mechanical properties of RC beams due to bond damage induced by electrochemical rehabilitation,” Constr. Build. Mater., vol. 237, 2020, doi: 10.1016/j.conbuildmat.2019.117629.

[39] M. T. Selvi and T. S. Thandavamoorthy, "Studies on the Properties of Steel and Polypropylene Fiber Reinforced Concrete without any Admixture," Int. J. Eng. Innov. Technol., vol. 3, no. 1, pp. 411-416, 2013. 